Chiu, W. T., \& Ho, Y. S. (2021). Bibliometrics of Latin American research on COVID-19 in the first year of the pandemic: the main trends. Revista de Biología Tropical, 69(4), 13061321. https://doi.org/10.15517/rbt.v69i4.48189

Biologín Tropical

BIOMEDICINA

https://doi.org/10.15517/rbt.v69i4.48189

\title{
Bibliometrics of Latin American research on COVID-19 in the first year of the pandemic: the main trends
}

Wen-Ta Chiu1; (D) https://orcid.org/0000-0003-0749-1087

Yuh-Shan Ho ${ }^{1,2 *}$; (D) https://orcid.org/0000-0002-2557-8736

1. AHMC Health System, 500 East Main Street, Alhambra, California 91801, United States of America; wtchiu.tmu@gmail.com

2. Trend Research Centre, Asia University, No. 500, Lioufeng Road, Wufeng, Taichung 41354, Taiwan; ysho@asia.edu.tw (Correspondence*)

Received 24-VIII-2021. Corrected 02-XI-2021. Accepted 09-XII-2021.

\begin{abstract}
Introduction: An outbreak of the COVID-19 was appended in the central Chinese city of Wuhan in December 2019. Lots of related papers were published in the world since then.

Objective: This study aimed to identify and analyze the characteristics of COVID-19 publications in the Science Citation Index Expanded (SCI-EXPANDED) published by Latin Americans in 2020.

Methods: Documents including searching keywords in their title, abstract, or author keywords from SCIEXPANDED were assessed. The analyzed aspects covered characteristics of document types, languages, Web of Science categories, and journals. Publication performances of countries and institutions were evaluated by six publication indicators and two citation indicators.

Results: A lower percentage of articles and a higher percentage of Spanish language were found. Web of Science category of general and internal medicine published the most articles. The Clinics was the most popular journal. The Cadernos de Saude Publica and Revista da Associacao Medica Brasileira published the most publications and reviews, respectively. Brazil took a leading position in the six publication indicators. The University of São Paulo in Brazil was the most productive institution. Based on the number of citations from the Web of Science Core Collection since publication to the end of 2020, 10 most frequently cited publications were presented. In addition, the analysis of words in publication titles, author keywords, and KeyWords Plus was performed to find the main research focuses.

Conclusions: In 2020, a total of 3056 COVID-19 documents in SCI-EXPANDED were published by Latin Americans mainly in the Web of Science categories of 'general and internal medicine' and 'public, environmental and occupational health'. More letters and editorial materials and fewer articles were published in the first year of its outbreak. A higher percentage of Spanish and Portuguese publications was found. Brazil dominated the six publication indicators. The University of São Paulo in Brazil ranked top in all the six publication indicators while the Technological University of Pereira in Colombia had a higher impact for their first- and corresponding-author publications. Health and infection were the main research focuses.
\end{abstract}

Key words: SARS-CoV-2; front page; coronavirus; pandemic; research trends.

Well-known coronavirus-related infectious diseases such as the Severe Acute Respiratory Syndrome (SARS) in 2003 (Ksiazek et al., 2003), Middle East Respiratory Syndrome
Coronavirus (MERS-CoV) in 2013 (Cauchemez et al., 2013), and novel coronavirus (COVID-19) in 2019 that was appended in the central Chinese city of Wuhan in December 
2019 (Hui et al., 2020; Zhou et al., 2020). COVID-19 is not only a recently emerged disease but also a new research topic. The Web of Science has been used for bibliometric study on COVID-19 in the Annals of Translational Medicine (Yu et al., 2020), the Journal of Family and Community Medicine (Farooq et al., 2021), the Sao Paulo Medical Journal (de Oliveira et al., 2021), the Profesional de la Informacion (Herrera-Viedma et al., 2020), the Pharmacological Research (Su et al., 2021), and the high impact factor journals (López-López et al., 2020). COVID-19 and the emerging research in fields, for example, ophthalmology (Kalra et al., 2021), business and management (Verma \& Gustafsson, 2020), environmental studies (Usman \& Ho, 2021), endocrinology (Atlasi et al., 2021), and the nursing (Oh \& Kim, 2020) was concerned. Other related research was presented on the topic of cancer research in the era of COVID-19 (Van Hemelrijck et al., 2021), the effect of COVID-19 on the environment (Casado-Aranda et al., 2021), the application of artificial intelligence in the COVID-19 pandemic (Islam et al., 2021), the coronavirus during the first eight months of COVID-19 in 2020 (Furstenau et al., 2021), the human mobility behavior in COVID-19 (Benita, 2021), the machine learning approaches in controlling COVID-19 outbreaks (Chiroma et al., 2020), and the co-occurrence of COVID-19 publications (Al-Zaman, 2021). It was reported that a higher percentage of document types of editorial materials were published when SARS suddenly happened (Chiu et al., 2004). COVID-19 editorial materials in the beginning stage of the pandemic were analyzed (LópezLópez et al., 2021). The patterns of international collaboration on COVID-19 (Duan \& Xia, 2021; Grammes et al., 2020) were studies. COVID-19 pandemic-related research in Africa (Fonkou et al., 2021), in Iran (Shamsi et al., 2020), and in the Latin American contributions (Gregorio-Chaviano et al., 2020) were also reported. Gregorio-Chaviano et al. (2020) concluded that the results of regional participation in COVID-19 research are not only related to the number and exponential growth but also related to quality and excellence.

Due to the Web of Science being updated from time to time, the bibliometric study results cannot be repeated. We collected data from the Science Citation Index Expanded (SCIEXPANDED) for publications in 2020 after the Journal Citation Report (JCR) reported the journal impact factors. This study aimed to use bibliometric analysis to study COVID-19 related publications in the SCI-EXPANDED in 2020. Six publication indicators and two citation indicators were applied to evaluate publication performances of countries and institutes. Word analysis was used to find the research's main focuses.

\section{MATERIALS AND METHODS}

Data used in this study were retrieved from the Clarivate Analytics Web of Science, the online version of the Science Citation Index Expanded (SCI-EXPANDED) on 25 July 2021. The 2020 journal Impact Factor $\left(I F_{2020}\right)$ was reported in the Journal Citation Report (JCR) on June 30, 2021. According to the definition of journal impact factor, it is best to search documents published in 2020 from SCI-EXPANDED after $I F_{2020}$ were presented. It is reported that SCI-EXPANDED is mainly designed for researchers to find literature and is not used for bibliometric research (Ho, 2018; Ho, 2021a). Thus, it is always necessary to perform data processing, but directly obtain data from SCI-EXPANDED for bibliometric research. Recently, in extensive bibliometric research, by using the 'front page' (including the paper title, abstract, and author keywords in the paper) (Fu et al., 2012) as a filter resulted in a big difference in bibliometric studies (Ho, 2019a; Ho, 2020). KeyWords Plus provides additional search terms, which are extracted from paper titles cited by authors in their bibliography and footnotes in the ISI (now Clarivate Analytics) database, and greatly enhance the title terms and author author-keyword indexing (Garfield, 1990). It has been pointed out that documents that can only be searched through 
KeyWords Plus (KP) have nothing to do with the search subject (Fu \& Ho, 2015).

Only documents published in 2020 were collected. The search strategies including Latin American countries: "Antigua \& Barbu", Argentina, Aruba, Bahamas, Barbados, Belize, Bolivia, Brazil, Chile, Colombia, "Costa Rica", Cuba, Curacao, Dominica, "Dominican Rep", "French Guiana", Ecuador, "El Salvador", Grenada, Guadeloupe, Guatemala, Guyana, Haiti, Honduras, Jamaica, Martinique, Mexico, Montserrat, Nicaragua, Panama, Paraguay, Peru, "Puerto Rico", "St Kitts \& Nevi", "St Vincent", Grenadines, Suriname, "Trinidad Tobago", Uruguay, and Venezuela and search keywords: "COVID-19", "SARS-CoV-2", "coronavirus disease 2019", "severe acute respiratory syndrome coronavirus 2", "2019-nCoV", "2019 novel coronavirus", "COVID19", "novel coronavirus 2019", "corona virus disease 2019", "COVID-2019", "COVD-19", and "novel coronavirus disease-19" were searched in terms of the country (CU) as well as title (TI), abstract (AB), and author keywords (AK). A total of 3056 documents were searched out as COVID-19 related publications by the Latin Americans after its outbreak for a year. These records were checked and downloaded into spreadsheet software, and additional coding was manually performed using Microsoft Excel 2016 for calculation (Li \& Ho, 2008; Ho, 2021b).

In the SCI-EXPANDED, the corresponding author is labeled as reprint author, but in this study, we used the term corresponding author (Ho, 2012). In a single-institute publication where the corresponding author institution is unspecified, the single institute is classified as the first and the corresponding author institution (Ho, 2014). In a single-author publication with multiple affiliations, only the affiliation in the Latin Americans was considered. In multiple corresponding-authors publications, the Latin American corresponding author, institute, and the country as the corresponding author information first and then the last corresponding author, institute, and country being designated as the corresponding author information
(Ho, 2019b). To have accuracy analysis results, affiliations originating from England, Scotland, Northern Ireland, Wales, Anguilla, and British Virgin Isl (British Virgin Islands) were reclassified as being from the UK (United Kingdom) (Chiu \& Ho, 2005). Affiliations from Curacao and French Guiana were reclassified as being from Netherlands and France, respectively.

Two citation indicators such as the total number of citations from Web of Science Core Collection in $2020\left(T C_{2020}\right.$ ) (Chuang et al., 2011; Wang et al., 2011) and the total number of citations per publication $\left(C P P_{2020}=T C_{2020}\right.$ ' $T P)$ (Ho, 2012) were used to characterize the publications.

\section{RESULTS}

Document types and languages: In recent years, the number of authors per publication $(A P P)$, citations per publication $\left(C P P_{\text {year }}\right)$, and the number of publications $(T P)$ were proposed to compare characteristics of document types (Monge-Nájera \& Ho, 2017). Using the citation indicator of $C P P_{\text {year }}$ gives values more accurate (Ho \& Ho, 2015; Monge-Nájera \& Ho, 2015). In 2020, 3056 COVID-19 related documents by the Latin Americans were found in SCI-EXPANDED within 11 document types indexed in the Web of Science. Table 1 shows that the most common document type was the articles (46\% of the 3056 documents). Document type of data papers with three documents had the highest $C P P_{2020}$ of 20 followed by proceedings papers with $C P P_{2020}$ of 17 respectively. The data papers also had the highest $A P P$ of 50. A total of 580 letters were published in 260 different journals. The Travel Medicine and Infectious Disease with $I F_{2020}$ of 6.211 published the most of 26 letters $(4.5 \%$ of the 580 letters) with a $C P P_{2020}$ of 7.9 and an $A P P$ of 6.3; followed by the Lancet with $I F_{2020}$ of 79.321 (18 letters; $3.1 \%$ of the 580 letters) with a $C P P_{2020}$ of 8.9 and an $A P P$ of 4.0 ; the World Neurosurgery with $I F_{2020}$ of 2.104 (18; $3.1 \%$ ) with a $C P P_{2020}$ of 0.39 and an $A P P$ of 4.4; the Revista Médica de Chile with $I F_{2020}$ of $0.553(17 ; 2.9 \%)$ with a $C P P_{2020}$ of 0.18 and 
TABLE 1

Characteristics of document type

\begin{tabular}{lcccccc}
\hline \multicolumn{1}{c}{ Document type } & $\mathrm{TP}$ & $\%$ & $\mathrm{AU}$ & $\mathrm{APP}$ & $\mathrm{TC}_{2020}$ & $\mathrm{CPP}_{2020}$ \\
\hline Article & 1397 & 46 & 13850 & 9.9 & 7613 & 5.4 \\
Letter & 580 & 19 & 2876 & 5.0 & 2386 & 4.1 \\
Editorial material & 501 & 16 & 2900 & 5.8 & 3229 & 6.4 \\
Review & 480 & 16 & 4086 & 8.5 & 3028 & 6.3 \\
Meeting abstract & 81 & 2.7 & 1033 & 13 & 0 & 0 \\
Correction & 12 & 0.39 & 174 & 15 & 0 & 0 \\
Data paper & 3 & 0.10 & 151 & 50 & 59 & 20 \\
News item & 3 & 0.10 & 4 & 1.3 & 1 & 0.33 \\
Proceedings paper & 2 & 0.065 & 15 & 7.5 & 34 & 17 \\
Book review & 1 & 0.033 & 1 & 1.0 & 0 & 0 \\
Reprint & 1 & 0.033 & 1 & 1.0 & 0 & 0 \\
\hline
\end{tabular}

$T P$ : number of publications; $A U$ : number of authors; $A P P(A U / T P)$ : number of authors $(A U)$ per publication $(T P) ; T C_{2020}$ : the total number of citations from Web of Science Core Collection since publication to the end of 2020; $C P P_{2020}:$ number of citations $\left(T C_{2020}\right)$ per publication $(T P)$.

an APP of 2.5; and the Arquivos Brasileiros de Cardiologia with $I F_{2020}$ of $2.000(15 ; 2.6 \%)$ with a $C P P_{2020}$ of 0.20 and an $A P P$ of 7.5 . A total of 501 editorial materials were published in 238 different journals, mainly in the Clinics with $I F_{2020}$ of 2.365 (47 editorial materials; $9.4 \%$ of the 501 editorial materials) with a $C P P_{2020}$ of 1.1 and an APP of 5.8; the Arquivos Brasileiros de Cardiologia with $I F_{2020}$ of 2.000 (23; $4.6 \%$ ) with a $C P P_{2020}$ of 1.3 and an $A P P$ of 4.0; and the Revista Médica de Chile with $I F_{2020}$ of $0.553(17 ; 3.4 \%)$ with a $C P P_{2020}$ of 0.24 and an $A P P$ of 5.2. A total of 480 reviews were published in 274 different journals. Nineteen percent of the 480 reviews were published in the top three productive journals: the Revista da Associação Médica Brasileira with $I F_{2020}$ of 1.209 (23 reviews; $4.8 \%$ of the 480 reviews) with a $C P P_{2020}$ of 0.70 and an $A P P$ of 5.2; the Clinics with $I F_{2020}$ of $2.365(19 ; 4.0 \%)$ with a $C P P_{2020}$ of 2.9 and an $A P P$ of 7.4 ; and the Frontiers in Immunology with $I F_{2020}$ of 7.561 $(12 ; 2.5 \%)$ with a $C P P_{2020}$ of 4.7 and an APP of 5.9.

There were seven languages in use. English, as the most popular language, comprised $92 \%$ of the 3056 COVID-19 related documents by the Latin Americans were found in SCI-EXPANDED, followed by Spanish (196 documents; $6.4 \%$ of 3056 documents) and Portuguese (47 documents), Other languages that were less used as follows, French (2 documents), and one in German, Polish, and Russian, respectively.

Web of Science Category and Journal: Journal Citation Reports (JCR) indexed 9531 journals with citation references across 178 Web of Science categories in SCI-EXPANDED in 2020. The 3056 COVID-19 related documents by the Latin Americans were published by 949 journals among the 138 Web of Science categories in SCI-EXPANDED. All 3056 COVID-19 related publications by Latin Americans were analyzed for further study.

The top three productive categories were: including general and internal medicine (473 documents; $15 \%$ ) with an APP of 7.4 and a $C P P_{2020}$ of 7.5 ; public, environmental, and occupational health $(380 ; 12 \%)$ with an $A P P$ of 7.0 and a $C P P_{2020}$ of 4.9 ; and infectious diseases $(232 ; 7.6 \%)$ with an $A P P$ of 7.3 and a $C P P_{2020}$ of 8.0. Other categories published more than 100 documents were: tropical medicine $(147 ; 4.8 \%)$, clinical neurology (135; $4.4 \%)$, immunology $(129 ; 4.2 \%)$, surgery (127; $4.2 \%)$, environmental sciences $(123 ; 4.0$ $\%)$, multidisciplinary sciences $(119 ; 3.9 \%)$, 
research and experimental medicine (110; 3.6 $\%)$, cardiac and cardiovascular systems (101; $3.3 \%$ ), and psychiatry $(101 ; 3.3 \%)$. One document published in categories of soil science and electrochemistry had the highest $A P P$ of 26 and $C P P_{2020}$ of 30 , respectively.

The top ten productive journals published in 40 or more documents were listed in Table 2. Total number of documents, percentages of articles, letters and editorial materials, and reviews, journal impact factor in $2020\left(I F_{2020}\right)$, number of authors per publication $(A P P)$, and citations per publication $\left(C P P_{2020}\right)$ were also compared. Clinics with $I F_{2020}$ of 2.365 (75 documents; $2.5 \%$ of 3056 documents) published the most documents including $9.3 \%$ articles, $64 \%$ of letters and editorial materials, and $25 \%$ reviews. Compared to the top ten productive journals, documents published in PLoS One had the highest APP of 10 while documents published in Travel Medicine and Infectious Disease had the highest $C P P_{2020}$ of 25 (Table 2). The journal with the highest $I F_{2020}$ of 91.245 was New England Journal of Medicine with eight documents including four articles, three letters, and one editorial material, with an $A P P$ of 20 , and a $C P P_{2020}$ of 167 , followed by Lancet $\left(I F_{2020}=79.321\right)$ with 29 documents including 18 letters, seven editorial materials, and four articles, with an APP of 8.0, and a $C P P_{2020}$ of 21, and JAMA-Journal of the American Medical Association $\left(I_{2020}=\right.$ 56.272 ) with two articles with an $A P P$ of 36 , and a $C P P_{2020}$ of 64 . These journals are the top three journals with $I F_{2020}$ in the category of general and internal medicine.

Publication Performances: Countries: A total of 3056 COVID-19 related publications by the 34 Latin American countries were found in SCI-EXPANDED, 1685 publications (55\% of 3056 publications) were singlecountry publications from 23 Latin American countries and 1371 (45\%) were internationally collaborative publications from 33 Latin American countries and other 121 countries in the world. Eleven of the 34 countries had no single-country publications. Only Belize had no internationally collaborative publication. Six, seven, and twenty countries had no first author, corresponding author, and first-author publications, respectively. The top 14 productive countries with 20 publications or more are listed in Table 3 with six publication indicators (Ho \& Kahn, 2014). Others were Honduras (18 publications), Guatemala (16), Dominican Republic (14), French Guiana (12), Barbados (11), Trinidad and Tobago (9), Jamaica (8),

TABLE 2

Top ten productive journals $(T P \geq 40)$

\begin{tabular}{lcccccccc}
\hline \multicolumn{1}{c}{ Journal } & $T P(\%)$ & $\% A$ & $\% L \& E$ & $\% R$ & $I F_{2020}$ & $A P P$ & $C P P_{2020}$ & Country \\
\hline Clinics & $75(2.5)$ & 9.3 & 64 & 25 & 2.365 & 6.8 & 1.6 & Brazil \\
Cadernos de Saude Publica & $71(2.3)$ & 82 & 15 & 1.4 & 1.632 & 4.7 & 2.3 & Brazil \\
Revista da Associacao Medica Brasileira & $68(2.2)$ & 24 & 43 & 34 & 1.209 & 5.5 & 0.43 & Brazil \\
Revista da Sociedade Brasileira de & $52(1.7)$ & 60 & 31 & 10 & 1.581 & 5.8 & 1.5 & Brazil \\
Medicina Tropical & & & & & & & & \\
Arquivos Brasileiros de Cardiologia & $50(1.6)$ & 16 & 76 & 8.0 & 2.000 & 7.2 & 1.0 & Brazil \\
PLoS One & $50(1.6)$ & 86 & $\mathrm{~N} / \mathrm{A}$ & 14 & 3.24 & 10 & 1.5 & USA \\
Medicina-Buenos Aires & $49(1.6)$ & 55 & 29 & 16 & 0.653 & 8.4 & 0.55 & Argentina \\
Revista Medica de Chile & $44(1.4)$ & 45 & 45 & 9.1 & 0.553 & 4.4 & 0.18 & Chile \\
International Journal of Environmental & $42(1.4)$ & 86 & 2.4 & 12 & 3.39 & 9.0 & 1.9 & Switzerland \\
Research and Public Health & & & & & & & & the UK \\
Travel Medicine and Infectious Disease & $40(1.3)$ & 7.5 & 80 & 13 & 6.211 & 7.3 & 25 &
\end{tabular}

$T P(\%)$ : total number of publications and percentage of total 3056 publications; $\% A$ : percentage of articles in a journal; \% $L \& E$ : percentage of letters and editorial materials in a journal; $\% R$ : percentage of reviews in a journal; $I F_{2020}:$ journal impact factor in 2020; $A P P$ : number of authors per publication; $C P P_{2020}$ : citations per publication $\left(T C_{2020} / T P\right)$. 


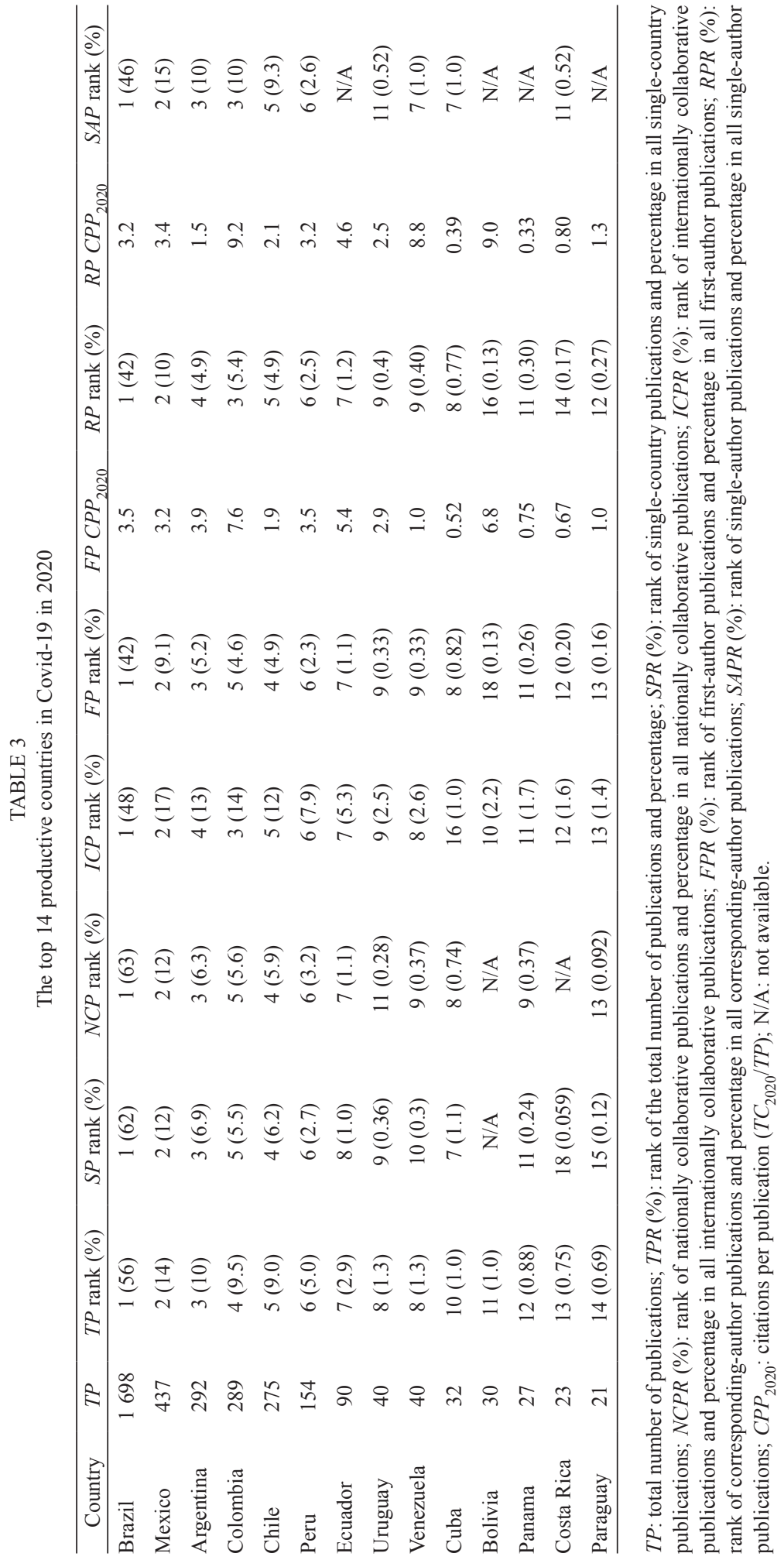


El Salvador (7), Nicaragua (7), Haiti (5), Saint Kitts and Nevis (5), Bahamas (4), Grenada (3), Antigua and Barbuda (2), Dominica (2), and one for each of Aruba, Belize, Curacao, Guyana, and Suriname. Brazil dominated in the seven publication indicators with a TP of 1698 publications (56\% of 3056 publications), an $I P$ of 1044 publications (62\% of 1685 singlecountry publications), an NCP of 687 publications $(63 \%$ of 1083 nationally collaborative publications), an ICP of 654 publications (48 $\%$ of 1371 internationally collaborative publications), an FP of 1294 publications (42\% of 3056 first-author publications), an $R P$ of 1268 publications (42\% of 2993 correspondingauthor publications), and an $S P$ of 89 publications (46\% of 194 single-author publications).

Publication Performances: Institutions: A total of 602 Covid-19 publications by the Latin Americans (20\% of 3056 publications) were single-institute publications $(S P)$ and 2 $454(80 \%)$ were inter-institutionally collaborative publications $(C P)$ including 1083 (44 $\%$ of 2454 inter-institutionally collaborative publications) nationally collaborative publications (NCP) and 1371 (56\%) internationally collaborative publications (ICP). Table 4 shows the 10 most productive Latin American institutions with 55 or more publications with seven publication indicators (Ho \& $\mathrm{Fu}, 2016$ ) and citation indicator, $C P P_{2020}$ of first-author and corresponding-author publications, respectively. Among these 10 institutions, seven institutions were located in Brazil and one in Chile, Colombia, and Mexico, respectively. The University of São Paulo (Brazil) dominated top in the seven publication indicators with total publications $(T P)$ of 409 (13\% of 3056 TP), single-institute publications $(S P)$ of 107 (18 $\%$ of $602 S P$ ), nationally collaborative publications $(N C P)$ of $160(15 \%$ of $1083 N C P)$, inter-institutionally collaborative publications $(I C P)$ of $142(10 \%$ of 1371 ICP), first-author publications $(F P)$ of $207(6.8 \%$ of $3056 F P)$, corresponding-author publications $(R P)$ of 205 (6.8\% of $2993 R P$ ), and singly-author publications $(S A P)$ of nine $(4.6 \%$ of 194 of $S A P)$.
Publication Performances: Authors: Publication indicators: total number of publications $(T P)$, number of first-author publications $(F P)$, number of corresponding-author publications $(R P)$, and number of single-author publications $(S A P)$ as well as citation indicators: citations per publication for first-author publications $\left(F P C P P_{2020}\right)$ and correspondingauthor publications $\left(R P C P P_{2020}\right)$ were proposed to compare publication performance of authors in a research topic (Giannoudis et al., 2021). Table 5 listed the top 16 most productive authors with 10 or more Covid-19 publications with the four publication indicators and the tow citation indicators. A. J. Rodriguez-Morales at the Technological University of Pereira in Colombia published the most Covid-19 publications in 2020 , followed distantly by other Latin America authors.

The 10 most frequently cited Covid-19 publications in the Latin Americans: Table 6 lists the 10 most frequently cited Covid19 publications in 2020 by the Latin Americans in SCI-EXPANDED with the citation indicator $T C_{2020}$. All the top ten publications including four articles, three editorial materials, two reviews, and one letter were an international collaboration by 172 institutions from 37 countries.

Research Focuses: A total of 331 publications (11\% of 3056 publications), 122 publications (6.9\% of 1781 publications with author keyword information), and 94 publications $(6.3 \%$ of 1484 publications with KeyWords Plus information) included 'patients', 'coronavirus infections', and 'infection', respectively. The results showed that 'health' including, for example, public health, mental health, telehealth, health care, and health policy and 'infection' including, for example, infections, co-infection, and infection control were the research focuses by the Latin Americans after COVID-19 outbreak for a year. Furthermore, 'pandemic' and 'Brazil' ranked not only in the top 20 words in publication title but also in the top 20 author keywords. 


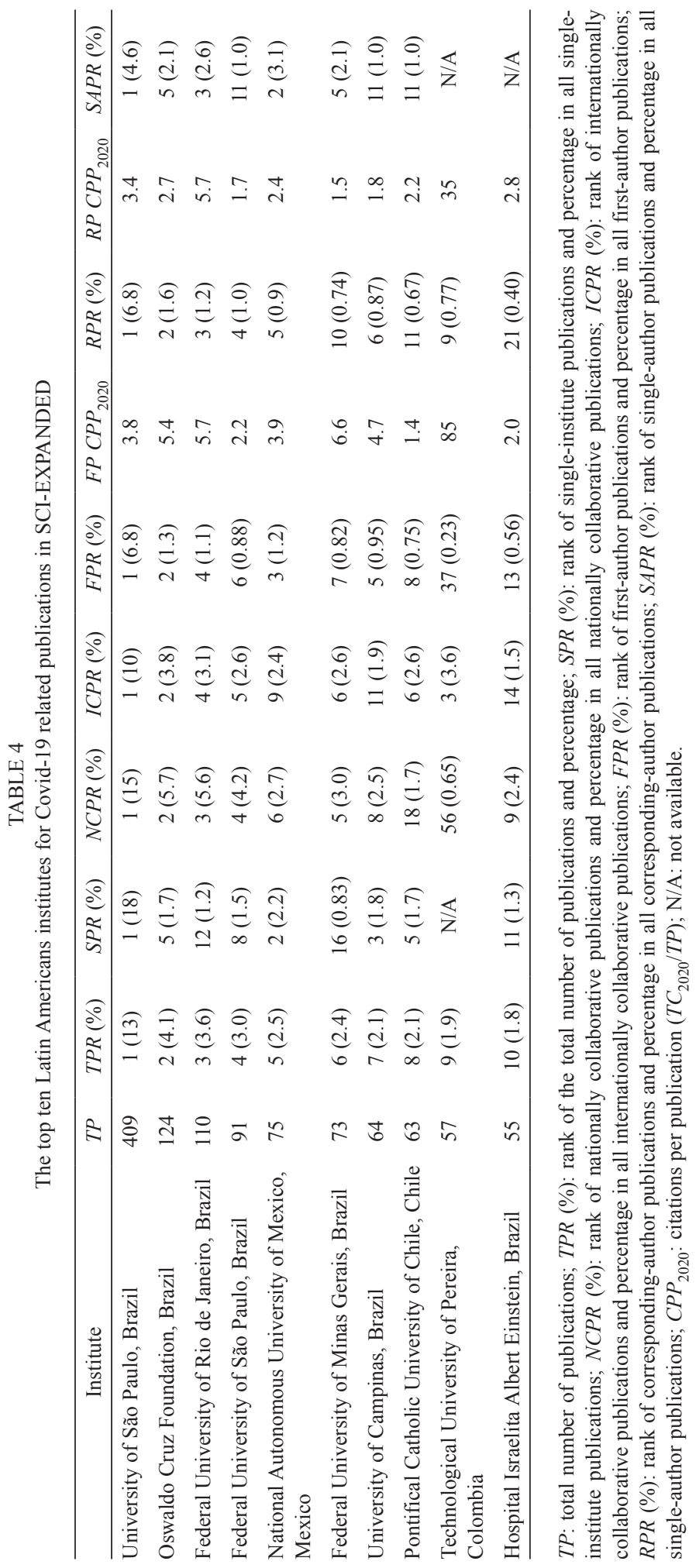


TABLE 5

The top 16 Latin Americans productive authors for Covid-19 in 2020

\begin{tabular}{lcccccc}
\hline \multicolumn{1}{c}{ Author } & rank $(T P)$ & $\operatorname{rank}(F P)$ & $F P C P P_{2020}$ & $\operatorname{rank}(R P)$ & $R P C P P_{2020}$ & rank (SAP) \\
\hline A.J. Rodriguez-Morales & $1(57)$ & $3(5)$ & 135 & $1(40)$ & 27 & N/A \\
D.K. Bonilla-Aldana & $2(22)$ & $212(1)$ & 5.0 & $250(1)$ & 56 & N/A \\
M. Giovanetti & $3(16)$ & $48(2)$ & 58 & N/A & N/A & N/A \\
C.D.F. de Souza & $4(15)$ & $1(13)$ & 1.0 & $2(13)$ & 0.62 & $2(3)$ \\
P.R.M. Rocco & $4(15)$ & N/A & N/A & $28(3)$ & 6.7 & N/A \\
W.B. de Carvalho & $6(14)$ & $8(4)$ & 1.8 & $11(5)$ & 3.8 & N/A \\
L.R. Moscote-Salazar & $6(14)$ & $48(2)$ & 0.50 & $11(5)$ & 0.40 & N/A \\
V.S. Santos & $6(14)$ & $212(1)$ & 8.0 & $53(2)$ & 6.5 & N/A \\
P.R. Martins & $9(13)$ & $3(5)$ & 5.4 & $4(6)$ & 4.5 & N/A \\
C. Franco-Paredes & $10(12)$ & $48(2)$ & 4.0 & $4(6)$ & 3.3 & $12(1)$ \\
E. Marchiori & $11(11)$ & $212(1)$ & 0 & $11(5)$ & 1.2 & N/A \\
H. Martelli & $11(11)$ & $8(4)$ & 0.75 & $250(1)$ & 1.0 & N/A \\
M.L.R. Neto & $11(11)$ & $48(2)$ & 20 & $3(8)$ & 30 & N/A \\
L.A. Hajjar & $14(10)$ & N/A & N/A & $250(1)$ & 8.0 & N/A \\
L.P. Kowalski & $14(10)$ & $212(1)$ & 99 & $53(2)$ & 50 & N/A \\
M.F. Lima-Costa & $14(10)$ & $22(3)$ & 1.3 & $28(3)$ & 1.3 & $12(1)$ \\
\hline
\end{tabular}

$T P$ : total number of publications; $F P$ : number of first-author publications; $R P$ : number of corresponding-author publications; $S A P$ : number of single-author publications; $F P C P P_{2020}$ : citations per publication $\left(T C_{2020} / F P\right) ; R P C P P_{2020}$ : citations per publication $\left(T C_{2020} / R P\right)$; N/A: not available.

'Mortality', 'ACE2', and 'pneumonia' were the top 20 most used author keywords and KeyWords Plus, respectively.

\section{DISCUSSION}

In 2020, 3056 COVID-19 publications in SCI-EXPANDED by Latin Americans were found in eleven document types. The COVID19 publication pattern in the first year of its outbreak suggests that more letters and editorial materials and fewer articles were published. It has been reported that document types of news, editorial materials, and letters were published more when SARS suddenly happened (Chiu et al., 2004). A higher percentage of Spanish publications was found. The Portuguese language was also used clearly. Three articles entitled "Protocol for a partially nested randomized controlled trial to evaluate the effectiveness of the scleroderma patient-centered intervention network COVID-19 home-isolation activities together (SPIN-CHAT) program to reduce anxiety among at-risk scleroderma patients" (Thombs et al., 2020a); "Inborn errors of type I IFN immunity in patients with life-threatening COVID-19" (Zhang et al., 2020); and "Changes in mental health symptoms from preCOVID-19 to COVID-19 among participants with systemic sclerosis from four countries: A Scleroderma Patient-centered Intervention Network (SPIN) Cohort study" (Thombs et al., 2020b) were published by more than 100 authors with 139, 129, and 101 respectively. An editorial material entitled "Fair allocation of scarce medical resources in the time of Covid19" (Emanuel et al., 2020) was published in May by Emanuel et al. from the USA, Canada, Brazil, the UK with the highest $T C_{2020}$ of 561 . A review entitled "Clinical, laboratory and imaging features of COVID-19: A systematic review and meta-analysis" (Rodriguez-Morales 
TABLE 6

The 10 most frequently cited Covid-19 publications SCI-EXPANDED by the Latin Americans

\begin{tabular}{|c|c|c|c|}
\hline$T C_{2020}$ & Title (document type) & Country & Reference \\
\hline 637 & $\begin{array}{l}\text { Remdesivir for the treatment of Covid-19: Final } \\
\text { report (article) }\end{array}$ & $\begin{array}{l}\text { USA, Spain, Greece, Singapore, } \\
\text { Japan, South Korea, Mexico, } \\
\text { Denmark, Germany, the UK }\end{array}$ & Beigel et al. (2020) \\
\hline 561 & $\begin{array}{l}\text { Fair allocation of scarce medical resources in the } \\
\text { time of Covid-19 (editorial material) }\end{array}$ & USA, Canada, Brazil, the UK & $\begin{array}{l}\text { Emanuel et al. } \\
(2020)\end{array}$ \\
\hline 490 & $\begin{array}{l}\text { Clinical, laboratory and imaging features of } \\
\text { COVID-19: A systematic review and meta- } \\
\text { analysis (review) }\end{array}$ & $\begin{array}{l}\text { Colombia, Peru, Bolivia, USA, } \\
\text { Mexico, Venezuela, Panama, } \\
\text { Honduras, Saudi Arabia, Indonesia, } \\
\text { India, Japan, China, Nepal }\end{array}$ & $\begin{array}{l}\text { Rodriguez-Morales } \\
\text { et al. }(2020)\end{array}$ \\
\hline 357 & $\begin{array}{l}\text { Using social and behavioural science to support } \\
\text { COVID-19 pandemic response (article) }\end{array}$ & $\begin{array}{l}\text { USA, Brazil, the UK, Poland, } \\
\text { Netherlands, China, Australia, } \\
\text { Canada }\end{array}$ & $\begin{array}{l}\text { Van Bavel et al. } \\
(2020)\end{array}$ \\
\hline 330 & $\begin{array}{l}\text { Effect of high vs low doses of chloroquine } \\
\text { diphosphate as adjunctive therapy for patients } \\
\text { hospitalized with severe acute respiratory } \\
\text { syndrome coronavirus } 2 \text { (SARS-CoV-2) infection: } \\
\text { A randomized clinical trial (article) }\end{array}$ & Brazil, Spain, Mozambique & Borba et al. (2020) \\
\hline 324 & $\begin{array}{l}\text { COVID-19: Towards controlling of a pandemic } \\
\text { (editorial material) }\end{array}$ & $\begin{array}{l}\text { Argentina, Sweden, the UK, Nigeria, } \\
\text { Canada, USA, Saudi Arabia, South } \\
\text { Korea, Senegal, Thailand, Germany }\end{array}$ & $\begin{array}{l}\text { Bedford et al. } \\
(2020)\end{array}$ \\
\hline 284 & $\begin{array}{l}\text { The effect of human mobility and control } \\
\text { measures on the COVID-19 epidemic in China } \\
\text { (article) }\end{array}$ & $\begin{array}{l}\text { the UK, USA, Ecuador, France, Italy, } \\
\text { China }\end{array}$ & $\begin{array}{l}\text { Kraemer et al. } \\
(2020)\end{array}$ \\
\hline 214 & $\begin{array}{l}\text { Real estimates of mortality following COVID-19 } \\
\text { infection (letter) }\end{array}$ & $\begin{array}{l}\text { Switzerland, China, USA, France, } \\
\text { French Guiana }\end{array}$ & Baud et al. (2020) \\
\hline 212 & $\begin{array}{l}\text { Hematologic, biochemical and immune biomarker } \\
\text { abnormalities associated with severe illness and } \\
\text { mortality in coronavirus disease } 2019 \text { (COVID- } \\
\text { 19): A meta-analysis (review) }\end{array}$ & Italy, USA, Brazil & Henry et al. (2020) \\
\hline 172 & $\begin{array}{l}\text { Practical recommendations for the management } \\
\text { of diabetes in patients with COVID-19 (editorial } \\
\text { material) }\end{array}$ & $\begin{array}{l}\text { Germany, the UK, Switzerland, } \\
\text { Italy, Singapore, USA, Netherlands, } \\
\text { France, Australia, Spain, Brazil, } \\
\text { China }\end{array}$ & $\begin{array}{l}\text { Bornstein et al. } \\
(2020)\end{array}$ \\
\hline
\end{tabular}

$T C_{2020}$ : the total number of citations from Web of Science Core Collection since publication year to the end of 2020.

et al., 2020) was published in March-April by Rodriguez-Morales et al. (2020) from Colombia, Peru, Bolivia, USA, Mexico, Venezuela, Panama, Honduras, Saudi Arabia, Indonesia, India, Japan, China, and Nepal with the highest $T C_{2020}$ of 490. In 2002, Garfield (2002) noted that a review with 350 citations within one year after publication was the highest citation recorded. A review with 738 citations in the year of publication and 1189 citations in the year after publication was reported (Ho \& Kahn, 2014).

Spanish is the main language in Latin Americans and the Portuguese language is mainly used in Brazil that is the most productive country in Latin Americans. Non-English 
documents had fewer citations, with a $C P P_{2020}$ of 0.91, while English documents had a $C P P_{2020}$ of 5.7. The non-English document with the highest $T C_{2020}$ was an article entitled "Food (in) security in the context of the SARS-CoV-2 pandemic" (Oliveira et al., 2020) published in Cadernos de Saúde Pública in Portuguese, with a $T C_{2020}$ of 15 .

The lower percentage of articles (46\% of all 3056 documents) compared with medical topics, for example, $69 \%$ in breast reconstruction (Li et al., 2020), $70 \%$ in Ebola (Pouris \& Ho, 2016), $75 \%$ in human papillomavirus (Lin et al., 2011), and $89 \%$ in fracture nonunion (Giannoudis et al., 2021) was found. Similarly, it was reported that a lower percentage of articles were published in the beginning stage of the SARS breakout in 2003 (Chiu et al. 2004).

The three core Web of Science categories published 997 documents (33\% of 3056 documents) including general and internal medicine (473 documents; $15 \%$ ), public, environmental and occupational health $(380 ; 12 \%)$, and infectious diseases $(232 ; 7.6 \%)$.

Clinics was the most popular journal. Documents published in Travel Medicine and Infectious Disease had the higher citations per publication. The top two most frequently cited papers were published in the New England Journal of Medicine with the highest $I F_{2020}$ of 91.245.

The first author and corresponding author are the two most contributed authors in a publication (Riesenberg \& Lundberg, 1990). At the institutional level, the determined institution of the corresponding author might be a home base of the study or origin of the paper (Ho, 2012). Six publication indicators: total number of publications $(T P)$, single-country publications $(S P)$, collaborative publications $(C P)$, firstauthor publications $(F P)$, corresponding-author publications $(R P)$, and single-author publications $(S A P)$ (Ho \& Kahn, 2014) were applied to compare publication performances. Brazil ranked top in all six publication indicators followed distantly by other Latin Americans. Domination in Covid-19 publications in the Latin Americans by Brazil was not surprising since this pattern occurs in other medical topics, for example, stroke (Alarcon-Ruiz et al., 2019), neurosciences (Forero et al., 2020), and bariatric surgery (Toro-Huamanchumo et al., 2021). Colombia ranked the top in two citation indicators, $C P P_{2020}$ of $F P$ and $R P$ with 7.6 and 9.2 , respectively. The USA had not only active collaborative research in Covid-19 with the Latin Americans (730 publications; $53 \%$ of 1 371 internationally collaborative publications) but also joined the top four highly cited Covid19 publications with the Latin Americans including an article by Beigel et al. (2020) with $T C_{2020}$ of 637 , an editorial material by Emanuel et al. (2020) with $T C_{2020}$ of 561, a review by Rodriguez-Morales et al. (2020) with $T C_{2020}$ of 490, and an article by Van Bavel et al. (2020) with $T C_{2020}$ of 357. In 2002, Garfield (2002) noted that a review with 350 citations within one year after publication was the highest citation recorded. Furthermore, a review by Lander et al. (2001) had 738 citations in the year of publication (Ho \& Kahn, 2014).

The University of São Paulo in Brazil dominated all the six publication indicators while the Technological University of Pereira in Colombia had a higher impact for their first- and corresponding-author publications. Compare the top ten institutes, publications with first authors and corresponding authors from the Technological University of Pereira (Colombia) had the highest $F P C P P_{2020}$ of 85 and $R P C P P_{2020}$ of 35 , respectively. Publications with first authors from the Pontifical Catholic University of Chile (Chile) had much lower FP CPP 2020 of 1.4 and publications with corresponding authors from the Federal University of Minas Gerais (Brazil) had $R P$ $C P P_{2020}$ of 1.5 .

Rodriguez-Morales also had the most 40 corresponding-author publications. C.D.F. de Souza at Federal University of Alagoas in Brazil had the most 13 first-author publications. Compare the top 16 authors in Table 5, Rodriguez-Morales had the greatest $C P P_{2020}$ for his first-author publications with 135 while D.K. Bonilla-Aldana had the greatest $C P P_{2020}$ for his corresponding-author publications with 
56. When the names of different authors are the same, or an author uses different names in his/ her publications (such as maiden surnames), there may be deviations in authorship analysis (Zhang et al., 2012).

The citation index of a publication might not be a direct measure of its quality or importance; it is a measure of recognition that may suggest its visibility or impact on the scientific community (Furlan \& Fehlings, 2006). Total citations (TC) from the Web of Science Core Collection are one of the popular bibliometric indicators used by authors in literature. However, it can be changed over time. Ho proposed a citation indicator of $T C_{\text {year }}$ to compare the most cited publications in a field (Ho, 2012; Ho, 2013). The advantage of $T C_{\text {year }}$ is that it is invariable and ensures repeatability in comparison to the index of citation from the Web of Science Core Collection (Fu et al., 2012).

USA was the most popular collaborative partner with nine publications, followed by the UK with six publications and Brazil and China with five publications respectively. Eleven Latin American countries published the top ten publications including Brazil with five publications, Mexico with two and one published by each of Argentina, Bolivia, Colombia, French Guiana, Ecuador, Honduras, Panama, Peru, and Venezuela respectively. Ten institutes had two of the top ten publications including the University of Oxford (the UK), Tan Tock Seng Hospital (Singapore), University of Southampton (UK), Harvard University (USA), University of California San Diego (USA), University of Washington (USA), University of Pennsylvania (USA), Peking University (China), Seoul National University Hospital (South Korea), and National Institute of Allergy and Infectious Diseases (NIAID) (USA). International collaborations with authors from outside of the Latin Americans had the top citations.

Analysis of used words in publication titles, abstracts, author keywords, and KeyWords Plus was proposed for the research focuses (Zhang et al., 2010). In SCI-EXPANDED, 1781 (58\% of 3056 publications) and 1484 (49\%) publications included author keywords and KeyWords Plus information, respectively. The analysis of words in publication titles, author keywords, and KeyWords Plus revealed that health and infection were the main research focuses.

Ethical statement: the authors declare that they all agree with this publication and made significant contributions; that there is no conflict of interest of any kind; and that we followed all pertinent ethical and legal procedures and requirements. All financial sources are fully and clearly stated in the acknowledgements section. A signed document has been filed in the journal archives.

\section{RESUMEN}

\section{Bibliometría de la investigación latinoamericana sobre COVID-19 en el primer año de la pandemia: principales tendencias}

Introducción: En diciembre de 2019 se produjo un brote de COVID-19 en la ciudad china de Wuhan. Desde entonces se publicaron muchos artículos relacionados en el mundo.

Objetivo: Este estudio tuvo como objetivo identificar y analizar las características de las publicaciones de COVID19 en el Science Citation Index Expanded (SCI-EXPANDED) realizadas por latinoamericanos en 2020.

Métodos: Se evaluaron los documentos que incluían palabras clave de búsqueda en su título, resumen o palabras clave de autor del SCI-EXPANDED. Los aspectos analizados cubrieron las características de los tipos de documentos, los idiomas, las categorías de la Web of Science y las revistas. El rendimiento de las publicaciones de los países e instituciones se evaluó mediante seis indicadores de publicación y dos indicadores de citación.

Resultados: Se encontró un bajo porcentaje de artículos y un mayor porcentaje en la lengua española. La categoría Web of Science de medicina general e interna fue la que más artículos publicó. The Clinics fue la revista más popular. Los Cadernos de Saude Publica y la Revista da Associacao Medica Brasileira fueron las que más publicaciones y revisiones publicaron, respectivamente. Brasil ocupó una posición destacada en los seis indicadores de publicación. La Universidad de São Paulo en Brasil fue la institución más productiva. Basándose en el número de citas de la Web of Science Core Collection desde la publicación hasta el final de 2020, se presentaron las 10 publicaciones más citadas. Además, se realizó el análisis de las palabras en los títulos de las publicaciones, las palabras clave del autor y KeyWords Plus para encontrar los principales focos de investigación. 
Conclusiones: En 2020, un total de 3056 documentos COVID-19 en SCI-EXPANDED fueron publicados por latinoamericanos, principalmente en las categorías de la Web of Science de 'medicina general e interna' y 'salud pública, ambiental y ocupacional'. Se publicaron más cartas y materiales editoriales y menos artículos en el primer año de su aparición. Se encontró un mayor porcentaje de publicaciones en español y portugués. Brasil dominó los seis indicadores de publicación. La Universidad de São Paulo, en Brasil, ocupó el primer puesto en los seis indicadores de publicación, mientras que la Universidad Tecnológica de Pereira, en Colombia, tuvo un mayor impacto en sus publicaciones de primer y segundo autor. La salud y la infección fueron los principales focos de investigación.

Palabras clave: SARS-CoV-2; portada; coronavirus; pandemia; tendencias de investigación.

\section{REFERENCES}

Al-Zaman, M. S. (2021). A bibliometric and co-occurrence analysis of COVID-19-related literature published between December 2019 and June 2020. Science Editing, 8(1), 57-63.

Alarcon-Ruiz, C. A., Diaz-Barrera, M. E., Vera-Monge, V. A., Alva-Diaz, C., \& Metcalf, T. (2019). A bibliometric analysis of the Latin American research on stroke 2003-2017. World Neurosurgery, 129, E545-E554.

Atlasi, R., Chakoli, A. N., Ramezani, A., TabatabaeiMalazy, O., \& Larijani, B. (2021). Scientometric analyzing the output of researchers and organizations on COVID-19 for better conducting the scientific efforts: With a glance to endocrinology. Journal of Diabetes and Metabolic Disorders, 20(1), 107-118.

Baud, D., Qi, X. L., Nielsen-Saines, K., Musso, D., Pomar, L., \& Favre, G. (2020). Real estimates of mortality following COVID-19 infection. Lancet Infectious Diseases, 20(7), 773.

Bedford, J., Enria, D., Giesecke, J., Heymann, D. L., Ihekweazu, C., Kobinger, G., Lane, H. C., Memish, Z., Oh, M. D., Sall, A. A., Schuchat, A., Ungchusak, K., \& Wieler, L. H. (2020). COVID-19: Towards controlling of a pandemic. Lancet, 395(10229), 1015-1018.

Beigel, J. H., Tomashek, K. M., Dodd, L. E., Mehta, A. K., Zingman, B. S., Kalil, A. C., Hohmann, E., Chu, H. Y., Luetkemeyer, A., Kline, S., de Castilla, D. L., Finberg, R. W., Dierberg, K., Tapson, V., Hsieh, L., Patterson, T. F., Paredes, R., Sweeney, D. A., Short, W. R., ... Lane, H. C. (2020). Remdesivir for the treatment of Covid-19: Final report. New England Journal of Medicine, 383(19), 1813-1826.

Benita, F. (2021). Human mobility behavior in COVID19: A systematic literature review and bibliometric analysis. Sustainable Cities and Society, 70, 102916.
Borba, M. G. S., Val, F. F. A., Sampaio, V. S., Alexandre, M. A. A., Melo, G. C., Brito, M., Mourao, M. P. G., Brito-Sousa, J. D., Baia-da-Silva, D., Guerra, M. V. F., Hajjar, L. A., Pinto, R. C., Balieiro, A. A. S., Pacheco, A. G. F., Santos, J. D. O., Naveca, F. G., Xavier, M. S., Siqueira, A. M., Schwarzbold, A., ... Lacerda, M. V. G. (2020). Effect of high vs low doses of chloroquine diphosphate as adjunctive therapy for patients hospitalized with severe acute respiratory syndrome coronavirus 2 (SARS-CoV-2) infection: A randomized clinical trial. JAMA Network Open, 3(4), e208857.

Bornstein, S. R., Rubino, F., Khunti, K., Mingrone, G., Hopkins, D., Birkenfeld, A. L., Boehm, B., Amiel, S., Holt, R. I. G., Skyler, J. S., DeVries, J. H., Renard, E., Eckel, R. H., Zimmet, P., Alberti, K. G., Vidal, J., Geloneze, B., Chan, J. C., Ji, L. N., \& Ludwig, B. (2020). Practical recommendations for the management of diabetes in patients with COVID-19. Lancet Diabetes \& Endocrinology, 8(6), 546-550.

Casado-Aranda, L. A., Sánchez-Fernández, J., \& Viedmadel-Jesús, M. I. (2021). Analysis of the scientific production of the effect of COVID-19 on the environment: A bibliometric study. Environmental Research, 193, 110416.

Cauchemez, S., Van Kerkhove, M. D., Riley, S., Donnelly, C. A., Fraser, C., \& Ferguson, N. M. (2013). Transmission scenarios for Middle East Respiratory Syndrome Coronavirus (MERS-CoV) and how to tell them apart. Eurosurveillance, 18(24), 7-13.

Chiroma, H., Ezugwu, A. E., Jauro, F., Al-Garadi, M. A., Abdullahi, I. N., \& Shuib, L. (2020). Early survey with bibliometric analysis on machine learning approaches in controlling COVID-19 outbreaks. PeerJ Computer Science, 6, e313.

Chiu, W. T., \& Ho, Y. S. (2005). Bibliometric analysis of homeopathy research during the period of 1991 to 2003. Scientometrics, 63(1), 3-23.

Chiu, W. T., Huang, J. S., \& Ho, Y. S. (2004). Bibliometric analysis of severe acute respiratory syndrome-related research in the beginning stage. Scientometrics, 61(1), 69-77.

Chuang, K. Y., Wang, M. H., \& Ho, Y. S. (2011). Highimpact papers presented in the subject category of water resources in the Essential Science Indicators database of the Institute for Scientific Information. Scientometrics, 87(3), 551-562.

de Oliveira, E. M. N., de Carvalho, A. R. B., Silva, J. S. E., Neto, A. R. D., Moura, M. E. B., \& de Freitas, D. R. J. (2021). Analysis of scientific production on the new coronavirus (COVID-19): A bibliometric analysis. Sao Paulo Medical Journal, 139(1), 3-9.

Duan, D. Z., \& Xia, Q. F. (2021). Evolution of scientific collaboration on COVID-19: A bibliometric analysis. Learned Publishing, 34(3), 429-441. 
Emanuel, E. J., Persad, G., Upshur, R., Thome, B., Parker, M., Glickman, A., Zhang, C., Boyle, C., Smith, M., \& Phillips, J. P. (2020). Fair allocation of scarce medical resources in the time of Covid-19. New England Journal of Medicine, 382(21), 2049-2055.

Farooq, R., Rehman, S., Ashiq, M., Siddique, N., \& Ahmad, S. (2021). Bibliometric analysis of coronavirus disease (COVID-19) literature published in Web of Science 2019-2020. Journal of Family and Community Medicine, 28(1), 1-7.

Fonkou, M. D. M., Bragazzi, N. L., Tsinda, E. K., Bouba, Y., Mmbando, G. S., \& Kong, J. D. (2021). COVID19 pandemic related research in Africa: Bibliometric analysis of scholarly output, collaborations and scientific leadership. International Journal of Environmental Research and Public Health, 18(14), 7273.

Forero, D. A. Trujillo, M. L., González-Giraldo, Y., \& Barreto, G. E. (2020). Scientific productivity in neurosciences in Latin America: A scientometrics perspective. International Journal of Neuroscience, 130(4), 398-406.

Fu, H. Z., \& Ho, Y. S. (2015). Top cited articles in thermodynamic research. Journal of Engineering Thermophysics, 24(1), 68-85.

Fu, H. Z., Wang, M. H., \& Ho, Y. S. (2012). The most frequently cited adsorption research articles in the Science Citation Index (Expanded). Journal of Colloid and Interface Science, 379(1), 148-156.

Furlan, J. C., \& Fehlings, M. G. (2006). A web-based systematic review on traumatic spinal cord injury comparing the "citation classics" with the consumers' perspectives. Journal of Neurotrauma, 23(2), 156-169.

Furstenau, L. B., Rabaioli, B., Sott, M. K., Cossul, D., Bender, M. S., Farina, E. M. J. D., Barcellos, F. N., Severo, P. P., Dohan, M. S., \& Bragazzi, N. L. (2021). A Bibliometric Network Analysis of Coronavirus during the First Eight Months of COVID-19 in 2020. International Journal of Environmental Research and Public Health, 18(3), 952.

Garfield, E. (1990). KeyWords Plus: ISI's breakthrough retrieval method. Part 1. Expanding your searching power on Current Contents on Diskette. Current Contents, 32, 5-9.

Garfield, E. (2002). Highly cited authors. Scientist, 16(7), $10-11$.

Giannoudis, P. V., Chloros, G. D., \& Ho, Y. S. (2021). A historical review and bibliometric analysis of research on fracture nonunion in the last three decades. International Orthopaedics, 45, 1663-1676.

Grammes, N., Millenaar, D., Fehlmann, T., Kern, F., Bohm, M., Mahfoud, F., \& Keller, A. (2020). Research output and international cooperation among countries during the COVID-19 pandemic: Scientometric analysis. Journal of Medical Internet Research, 22(12), e24514.

Gregorio-Chaviano, O., Limaymanta, C. H., \& LópezMesa, E. K. (2020). Bibliometric evaluation of Latin American contributions on COVID-19. Biomédica, 40(1), 104-115.

Henry, B. M., de Oliveira, M. H. S., Benoit, S., Plebani, M., \& Lippi, G. (2020). Hematologic, biochemical and immune biomarker abnormalities associated with severe illness and mortality in coronavirus disease 2019 (COVID-19): A meta-analysis. Clinical Chemistry and Laboratory Medicine, 58(7), 1021-1028.

Herrera-Viedma, E., Lopez-Robles, J. R., Guallar, J., \& Cobo, M. J. (2020). Global trends in coronavirus research at the time of Covid-19: A general bibliometric approach and content analysis using SciMAT. Profesional de la Información, 29(3), e290322.

Ho, H. C., \& Ho, Y. S. (2015). Publications in dance field in Arts \& Humanities Citation Index: A bibliometric analysis. Scientometrics, 105(2), 1031-1040.

Ho, Y. S. (2012). Top-cited articles in chemical engineering in Science Citation Index Expanded: A bibliometric analysis. Chinese Journal of Chemical Engineering, 20(3), 478-488.

Ho, Y. S. (2013). The top-cited research works in the Science Citation Index Expanded. Scientometrics, 94(3), 1297-1312.

Ho, Y. S. (2014). Classic articles on social work field in Social Science Citation Index: A bibliometric analysis. Scientometrics, 98(1), 137-155.

Ho, Y. S. (2018). Comments on "Mapping the scientific research on non-point source pollution: A bibliometric analysis" by Yang et al. (2017). Environmental Science and Pollution Research, 25(30), 30737-30738.

Ho, Y. S. (2019a). Some comments on: Mao et al. (2018) "Bibliometric analysis of insights into soil remediation" Journal of Soils and Sediments, 18(7): 2520-2534. Journal of Soils and Sediments, 19(10), 3657-3658.

Ho, Y. S. (2019b). Bibliometric analysis of the Journal of Orthopaedic Research from 1991 to 2018. Orthopedic Research Online Journal, 6(2), 574-584.

Ho, Y. S. (2020). Letter to the Editor Regarding "Bibliometric and Visualized Analysis of Stem Cells Therapy for Spinal Cord Injury Based on Web of Science and CiteSpace in the Last 20 Years". World Neurosurgery, 140, 423-427.

Ho, Y. S. (2021a). Comments on: Yeand Zhang (2019) 'visualizing the knowledge structure of medication-adherence research: A bibliometric analysis 
(1997-2016)', International Journal of Health Planning and Management, 34: 1333-1353. International Journal of Health Planning and Management, 36(4), 1349-1351.

Ho, Y. S. (2021b). A bibliometric analysis of highly cited publications in Web of Science category of emergency medicine. Signa Vitae, 17(1), 11-19.

Ho, Y. S., \& Fu, H. Z. (2016). Mapping of metal-organic frameworks publications: A bibliometric analysis Inorganic Chemistry Communications, 73, 174-182.

Ho, Y. S., \& Kahn, M. (2014). A bibliometric study of highly cited reviews in the Science Citation Index Expanded ${ }^{\mathrm{TM}}$. Journal of the Association for Information Science and Technology, 65(2), 372-385.

Hui, D. S., Azhar, E. I., Madani, T. A., Ntoumi, F., Kock, R., Dar, O., Ippolito, G., Mchugh, T. D., Memish, Z. A., Drosten, C., Zumla, A., \& Petersen, E. (2020). The continuing 2019-nCoV epidemic threat of novel coronaviruses to global health: The latest 2019 novel coronavirus outbreak in Wuhan, China. International Journal of Infectious Diseases, 91, 264-266.

Islam, M. M., Poly, T. N., Alsinglawi, B., Lin, L. F., Chien, S. C., Liu, J. C., \& Jian, W. S. (2021). Application of artificial intelligence in COVID-19 pandemic: Bibliometric analysis. Healthcare, 9(4), 441-451.

Kalra, G., Kaur, R., Ichhpujani, P., Chahal, R., \& Kumar, S. (2021). COVID-19 and ophthalmology: A scientometric analysis. Indian Journal of Ophthalmology, 69(5), 1234-1240

Kraemer, M. U. G., Yang, C. H., Gutierrez, B., Wu, C. H., Klein, B., Pigott, D. M., du Plessis, L., Faria, N. R., Li, R. R., Hanage, W. P., Brownstein, J. S., Layan, M., Vespignani, A., Tian, H. Y., Dye, C., Pybus, O. G., \& Scarpino, S. V. (2020). The effect of human mobility and control measures on the COVID-19 epidemic in China. Science, 368(6490), 493-497.

Ksiazek, T. G., Erdman, D., Goldsmith, C. S., Zaki, S. R., Peret, T., Emery, S., Tong, S. X., Urbani, C., Comer, J. A., Lim, W., Rollin, P. E., Dowell, S. F., Ling, A. E., Humphrey, C. D., Shieh, W. J., Guarner, J., Paddock, C. D., Rota, P., Fields, B., ... Anderson, L. J. (2003). A novel coronavirus associated with severe acute respiratory syndrome. New England Journal of Medicine, 348(20), 1953-1966.

Lander, E. S., Linton, L. M., Birren, B., Nusbaum, C., Zody, M. C., \& Baldwin, J. (2001). Initial sequencing and analysis of the human genome. Nature, 409(6822), 860-921.

Li, Z., \& Ho, Y. S. (2008). Use of citation per publication as an indicator to evaluate contingent valuation research. Scientometrics, 75(1), 97-110.

Li, Y. Z., Wang, X. J., Thomsen, J. B., Nahabedian, M. Y., Ishii, N., Rozen, W. M., Long, X., \& Ho, Y. S.
(2020). Research trends and performances of breast reconstruction: A bibliometric analysis. Annals of Translational Medicine, 8(22), 1529.

Lin, H. W., Yu, T. C., \& Ho, Y. S. (2011). A systemic review of human papillomavirus studies: Global publication comparison and research trend analyses from 1993 to 2008. European Journal of Gynaecological Oncology, 32(2), 133-140.

López-López, W., Salas, G., Vega-Arce, M., CornejoAraya, C. A., Barboza-Palomino, M., \& Ho, Y. S. (2020). Publications on COVID-19 in high impact factor journals: A bibliometric analysis. Universitas Psychologica, 19, 1-12.

López-López, W., Vega-Arce, M., Salas, G., Urzúa, A. Torres-Fernández, I., \& Ho, Y. S. (2021). Bibliometric analysis of COVID-19 editorial materials in the beginning stage of the pandemic. Malaysian Journal of Library \& Information Science, 26(1), 103-116.

Monge-Nájera, J., \& Ho, Y. S. (2015). Bibliometry of Panama publications in the Science Citation Index Expanded: Publication type, language, fields, authors and institutions. Revista de Biología Tropical, 63(4), $1255-1266$.

Monge-Nájera, J., \& Ho, Y. S. (2017). El Salvador publications in the Science Citation Index Expanded: subjects, authorship, collaboration and citation patterns. Revista de Biología Tropical, 65(4), 1428-1436.

Oh, J., \& Kim, A. (2020). A bibliometric analysis of COVID-19 research published in nursing journals. Science Editing, 7(2), 118-124.

Oliveira, T. C., Abranches, M. V., \& Lana, R. M. (2020). Food (in) security in the context of the SARSCoV-2 pandemic. Cadernos de Saúde Pública, 36(4), e00055220.

Pouris, A., \& Ho, Y. S. (2016). A bibliometric analysis of research on Ebola in Science Citation Index Expanded. South African Journal of Science, 112(3), 83-88.

Riesenberg, D., \& Lundberg, G. D. (1990), The order of authorship: Who's on first. JAMA-Journal of the American Medical Association, 264(14), 1857.

Rodriguez-Morales, A. J., Cardona-Ospina, J. A., Gutiérrez-Ocampo, E., Villamizar-Peña, R., Holguin-Rivera, Y., Escalera-Antezana, J. P., Alvarado-Arnez, L. E., Bonilla-Aldana, D. K., Franco-Paredes, C., Henao-Martinez, A. F., Paniz-Mondolfi, A., LagosGrisales, G. J., Ramírez-Vallejo, E., Suárez, J. A., Zambrano, L. I., Villamil-Gómez, W. E., BalbinRamon, G. J., Rabaan, A. A., Harapan, H., ... Sah, R. (2020). Clinical, laboratory and imaging features of COVID-19: A systematic review and meta-analysis. Travel Medicine and Infectious Disease, 34, 101623.

Shamsi, A., Mansourzadeh, M. J., Ghazbani, A., Khalagi, K., Fahimfar, N., \& Ostovar, A. (2020). Contribution 
of Iran in COVID-19 studies: A bibliometrics analysis. Journal of Diabetes and Metabolic Disorders, 19(2), 1845-1854.

Su, M. M., Xu, S. W., \& Weng, J. P. (2021). A bibliometric study of COVID-19 research in Web of Science. Pharmacological Research, 169, 105664.

Thombs, B. D., Kwakkenbos, L., Carrier, M. E., Bourgeault, A., Tao, L. D., Harb, S., Gagarine, M., Rice, D., Bustamante, L., Ellis, K., Duchek, D., Wu, Y., Bhandari, P. M., Neupane, D., Carboni-Jimenez, A., Henry, R. S., Krishnan, A., Sun, Y., Levis, B., ... Ostbo, N. (2020a). Protocol for a partially nested randomised controlled trial to evaluate the effectiveness of the scleroderma patient-centered intervention network COVID-19 home-isolation activities together (SPIN-CHAT) program to reduce anxiety among atrisk scleroderma patients. Journal of Psychosomatic Research, 135, 110132.

Thombs, B. D., Kwakkenbos, L., Henry, R. S., Carrier, M. E., Patten, S., Harb, S., Bourgeault, A., Tao, L., Bartlett, S. J., Mouthon, L., Varga, J., Benedetti, A., Fortune, C., Gietzen, A., Guillot, G., Lewis, N., Richard, M., Sauve, M., Welling, J., ... Ellis, K. (2020b). Changes in mental health symptoms from pre-COVID-19 to COVID-19 among participants with systemic sclerosis from four countries: A Scleroderma Patient-centered Intervention Network (SPIN) Cohort study. Journal of Psychosomatic Research, 139, 110262 .

Toro-Huamanchumo, C. J., Morán-Mariños, C., SalazarAlarcon, J. L., Barros-Sevillano, S., HuamanchumoSuyon, M. E., \& Salinas-Sedo, G. (2021). Latin American research on bariatric surgery: A bibliometric study. Obesity Surgery, 31(4), 1869-1876.

Usman, M., \& Ho, Y. S. (2021). COVID-19 and the emerging research trends in environmental studies: A bibliometric evaluation. Environmental Science and Pollution Research, 28(14), 16913-16924.

Van Bavel, J. J., Baicker, K., Boggio, P. S., Capraro, V., Cichocka, A., Cikara, M., Crockett, M. J., Crum, A. J., Douglas, K. M., Druckman, J. N., Drury, J., Dube, O., Ellemers, N., Finkel, E. J., Fowler, J. H., Gelfand, M., Han, S. H., Haslam, S. A., Jetten, J., ... Willer, R. (2020). Using social and behavioural science to support COVID-19 pandemic response. Nature Human Behaviour, 4(5), 460-471.

Van Hemelrijck, M., Lewison, G., Fox, L., Vanderpuye, V. D., Murillo, R., Booth, C. M., Canfell, K., Pramesh, C., Sullivan, R., \& Mukherij, D. (2021). Global cancer research in the era of COVID-19: A bibliometric analysis. Ecancermedicalscience, 15, 1264-1274.

Verma, S., \& Gustafsson, A. (2020). Investigating the emerging COVID-19 research trends in the field of business and management: A bibliometric analysis approach. Journal of Business Research, 118, 253-261.

Wang, M. H., Fu, H. Z., \& Ho, Y. S. (2011). Comparison of universities' scientific performance using bibliometric indicators. Malaysian Journal of Library \& Information Science, 16(2), 1-19.

Yu, Y., Li, Y., Zhang, Z., Gu, Z., Zhong, H., Zha, Q., Yang, L., Zhu, C., \& Chen, E. (2020). A bibliometric analysis using VOSviewer of publications on COVID-19. Annals of Translational Medicine, 8(13), 1-11.

Zhang, Q., Bastard, P., Liu, Z. Y., Le Pen, J., MoncadaVelez, M., Chen, J., Ogishi, M., Sabli, I. K. D., Hodeib, S., Korol, C., Rosain, J., Bilguvar, K., Ye, J. Q., Bolze, A., Bigio, B., Yang, R., Arias, A. A., Zhou, Q. H., Zhang, Y., .... Casanova, J. L. (2020). Inborn errors of type I IFN immunity in patients with life-threatening COVID-19. Science, 370(6515), 422-eabd4570.

Zhang, J., Wang, M. H., \& Ho, Y. S. (2012). Bibliometric analysis of aerosol research in meteorology and atmospheric sciences. International Journal of Environment and Pollution, 49(1), 16-35.

Zhang, G. F., Xie, S. D., \& Ho, Y. S. (2010). A bibliometric analysis of world volatile organic compounds research trends. Scientometrics, 83(2), 477-492.

Zhou, F., Yu, T., Du, R., Fan, G., Liu, Y., Liu, Z., Xiang, J., Wang, Y., Song, B., Gu, X., Guan, L., Wei, Y., Li, H., Wu, X., Xu, J., Tu, S., Zhang, Y., Chen, H., \& Cao, B. (2020). Clinical course and risk factors for mortality of adult inpatients with COVID-19 in Wuhan, China: A retrospective cohort study. Lancet, 395(10229), 1054-1062. 